Rhode Island College

Digital Commons @ RIC

Master's Theses, Dissertations, Graduate

Master's Theses, Dissertations, Graduate

Research and Major Papers Overview

Research and Major Papers

4-2009

\title{
Transgressive Masculinities in Selected Sword and Sandal Films
}

Merle Kenneth Peirce

Rhode Island College

Follow this and additional works at: https://digitalcommons.ric.edu/etd

Part of the Film and Media Studies Commons, Gender and Sexuality Commons, and the Lesbian, Gay,

Bisexual, and Transgender Studies Commons

\section{Recommended Citation}

Peirce, Merle Kenneth, "Transgressive Masculinities in Selected Sword and Sandal Films" (2009). Master's Theses, Dissertations, Graduate Research and Major Papers Overview. 19.

https://digitalcommons.ric.edu/etd/19

This Thesis is brought to you for free and open access by the Master's Theses, Dissertations, Graduate Research and Major Papers at Digital Commons @ RIC. It has been accepted for inclusion in Master's Theses, Dissertations, Graduate Research and Major Papers Overview by an authorized administrator of Digital Commons @ RIC. For more information, please contact digitalcommons@ric.edu. 


\title{
TRANSGRESSIVE MASCULINITIES IN SELECTED SWORD AND SANDAL FILMS \\ By
}

\author{
Merle Kenneth Peirce \\ A Thesis Submitted in Partial Fulfillment \\ of the Requirements for the Individualised Masters' Programme \\ In \\ the Departments of \\ Modern Languages, \\ English \\ and
}

Film Studies

Rhode Island College

2009 


\begin{abstract}
In the ancient film epic, even in incarnations which were conceived as patriarchal and hetero-normative works, small and sometimes large bits of transgressive gender formations appear. Many overtly hegemonic films still reveal the existence of resistive structures buried within the narrative. Film criticism has generally avoided serious examination of this genre, and left it open to the purview of classical studies professionals, whose view and value systems are significantly different to those of film scholars.

This paper examines significant films in the ancient epic canon from a queer theoretical viewpoint, to survey the extent of atypical gender formations within the genre. Working with the studies of Judith Butler and Michel Foucault, augmented with critiques by Steve Neale and Ina Rae Hark, the extent of such trangressions became clear.

The ancient epic film displayed the traits of transgressive gender construction and the homoerotic display of the male first noted in Baron Wilhelm von Gloeden's classically themed tableaux of nude males. Classicism was then, and remains today, a trompe l'oeuil which misleads the spectator, tricking him into accepting the unthinkable.
\end{abstract}




\section{Table of Contents}

$\begin{array}{ll}\text { Introduction } & 1\end{array}$

$\begin{array}{ll}\text { Cabiria } & 17\end{array}$

Ben- Hur: A Tale of the Christ 24

Sign of the Cross $\quad 31$

$\begin{array}{ll}\text { Spartacus } & 35\end{array}$

Fellini Satyricon $\quad 45$

Gladiator $\quad 52$

$\begin{array}{ll}\text { Conclusion } & 60\end{array}$

Endnotes 63

Selected Bibliography 66

Filmography $\quad 70$ 
In 1876, Baron Wilhelm von Gloeden (1856-1931) landed at Taormina, Sicily to begin an artist's career which would see him become a world renowned master of pseudo-classic homo-erotic art. His photographs of young Sicilian boys, naked, and in poses inspired by classical Greek and Roman statuary, became strangely acceptable as ethnographic and classical studies. His work was displayed in museums, won prizes at photographic exhibitions, and seized the attention of prominent artists and littérateurs. Von Gloeden's special view inspired a school of imitators, such as Vincenzo Galdi (1871-1961), Baron Corvo (Frederick William Rolfe, 1860-1913), Gaetano d'Agata (1883-1949) and his own cousin, Wilhelm von Pluschöw (1852-1930), as well as the Americans, Fred Holland Day (1864-1933) and Thomas F. Eakins (1844-1916).

The noted French critic Roland Barthes remarked "The art of von Gloeden is an adventure of feelings because he produced a world of his own. . . that is simultaneously truthful and unlikely, false (to an extreme), a paradox madder than the maddest dream." He went on to characterise in "the Baron's photographs a force rather than an art: a force both delicate and powerful and because of which he resisted all conformity - of art, of morality, and of politics, ${ }^{2}$ underscoring the transgressive nature of von Gloeden's art. Barthes was an intellectual giant, a Cocteau without a camera. His work with structuralism, semiotics and literature gave him an unusual and unique position. The resistance he noticed in von Gloeden's images has, in film, most often surfaced in the ancient film epic, where temporal distance and costuming conventions allow a freedom not easily available 
in other genres.

Later practitioners of the motion picture art such as Giovanni Pastrone in Italy and Fred Niblo in the United States, followed von Gloeden's lead in view and context, establishing a tradition of homo-erotic gaze and masculine appreciation within the ancient Graeco-Roman film epic. From Giovanni Pastrone's Cabiria (1914), with its presentation of the ruggedly muscular and hyper-masculine Maciste (Bartolomeo Pagano), to the exaltation of Ramon Novarro's refined, ephebic Judah Ben-Hur, coupled with a more restrained appreciation of Francis X. Bushman's aggressive portrayal of Messala in the 1925 Ben-Hur (echoing Pagano's muscularity), the early Graeco-Roman film epic was unabashedly voyeuristic, and the epic regularly resurfaces in times of stress when heterosexual patterns of masculinity are under attack. By clarifying issues of power and identity, the homoerotic confirms and strengthens heterosexual identity, usually in the context of a sexual or sexualized fantasy, often embodying dreams of mastery and desire or desirability. Judith Butler argues that heterosexuality is by its nature defined by the homosexual ethos which it fears and prohibits.

In other words, for heterosexuality to remain intact as a distinct social form, it requires an intelligible conception of homosexuality and also requires the prohibition of that conception in rendering it culturally unintelligible ... heterosexuality is the laborious construction based upon their [bisexuality and homosexuality] gradual repression. ${ }^{3}$

Homosexuality in this case becomes the dominant member of the heterosexual - 
homosexual binary, as it is the one which gives definition and meaning to its partner. Thus, as we move into film, it is a restricted number of genres that reveal this interplay of sexualities, prime among which is the ancient film epic.

The epic is nearly always an extreme undertaking, filled with lushness and excess, as exemplified by Carmine Gallone's Scipione l'Africano (1937), Cecil B. DeMille's Cleopatra (1934), or Gabriel Pascal's Caesar and Cleopatra (1948). Thus it embodies elegance, refinement, and decadence, themes which are open to exploitation of the homo-erotic in a unique visual manner. Using the theory and methodology of Gender Studies and Queer Theory, and specifically the work of Michel Foucault and Judith Butler, I will follow the progress of the ancient epic, specializing in its Roman and Aegypto-Roman incarnations, and examining representations of the male body and the nature of the homo-erotic gaze in these films. The manner in which masculinity is portrayed in the ancient film epic, often cloaks erotic images with adoration of classical themes and settings, recalling von Gloeden's own approach as an assembler of images, and determines the manner in which these epics raise the issue of, and delineate the homo-erotic, and explore the inner tension created by male homo-erotic expression in the filmic text and societal demands for hetero-normativity. I will visit, in particular, the films Cabiria (Giovanni Pastrone, 1914), Ben-Hur (Fred Niblo, 1925 and William Wyler, 1959), Sign of the Cross, (Cecil B. DeMille, 1932), Spartacus (Stanley Kubrick, 1960), Fellini Satyricon (Federico Fellini, 1970), and Gladiator (Ridley Scott,2000).

The tradition of the ancient epic in film is a long one. In her introduction to 
Big Screen Rome, Monica Silveira Cyrino comments on its substantial and enduring popularity.

Of all the cinematic descriptions of antiquity, the image of ancient Rome on the big screen has long been the most popular and ubiquitous, as well as the most impressive and meaningful. The idea of ancient Rome, city of power, intrigue, beauty, brutality and lust, has always attracted and entertained modern film audiences. Films about the ancient Roman world have been wildly popular and immensely profitable throughout the first century of $t$ he history of cinema, and the genre continues to show signs of strength. ${ }^{4}$ The ancient epic made its appearance at the beginning of the new century. In 1900, scarcely six years after the introduction of the motion Picture, Britain's Robert W. Paul produced The Last Days of Pompeii, based on Sir Edward BulwerLytton's novel of the same name published in 1834. In the years following its appearance in 1895, Henryk Sienkiewicz's novel Quo Vadis: A Narrative of the Time of Nero became immensely popular, and his extensive efforts in epic fiction generally, led to a Nobel prize in 1905. In 1902, Quo Vadis was made into a film in France by the directors Lucien Nonguet and Ferdinand Zecca. In 1907, in the U. S., Kalem Studios filmed Lew Wallace's Ben-Hur: A Tale of the Christ (1880), without permission, prompting a battle over copyright infringement, which the studio lost in 1911.

Between 1905 and 1915, the ancient epic became the basis for a succession of Italian super spectaculars which were often based on ancient historical figures 
such as Nero - Nerone (Luigi Maggi, 1909), Julius Caesar - Giulio Cesare (Giovanni Pastrone, 1909), Messalina (third wife of the Emperor Claudius) - Messalina (Mario Caserini, 1910) or Spartacus, the leader of the Slave Revolt in 73 - 71 B. C. Spartaco (Giovanni Enrico Vidali, 1913). Historical fiction formed the basis for other films, The Last Days of Pompeii - Gli Ultimi Giorni di Pompeii (Arturo Ambrosio and Luigi Maggi, 1908 and Mario Caserini and Eleuterio Rodolfi, 1913), Quo Vadis? as Quo Vadis? (Enrico Guazzoni, 1912), and Emilio Salgari's Cartagine in Flamme - Cabiria - Visione Storica del Terzo Secolo A.C. (Giovanni Pastrone, 1914). In the U. S., Frederick A. Thomson produced Sign of the Cross, based on a play by Wilson Barrett for Jesse Lasky - Famous Players in 1914.

Following the Great War (1914-1918), there was a renewed interest in the ancient epic, but on a much reduced scale. Maciste films continued to be made in Italy up until 1926-1927, sometimes starring Bartolomeo Pagano. The Maciste films usually involved a character of great physical strength and prowess, in effect, a reconstituted Hercules figure. Gabriellino D'Annunzio and Georg Jacoby directed a remake of Quo Vadis in 1926, but it was ill-received. In the U. S., Fred Niblo's BenHur (1925) became a great sensation despite a very troubled start.

Cecil B. DeMille produced his most decadent remake of Sign of the Cross for Paramount. The Samuel Goldwyn Company released the burlesque Roman Scandals, directed by Frank Tuttle in 1933. The film is memorable for its send up of the chariot race in Ben-Hur. In 1934, DeMille made Cleopatra, which was excoriated by Italian critics, and was booed by some audiences. The last epics of 
the inter war period were Carmine Gallone's Italian epic Scipio l'Africano, a propaganda piece sponsored by Benito Mussolini, and in England, Alexander Korda's unfinished $I$, Claudius. London Films was in a difficult financial position at the time (1937). The star, Charles Laughton, and the director, Joseph von Sternberg did not get along, and the production was behind schedule. When co-star Merle Oberon was injured in an automobile accident, Korda used it as an excuse to wrap up the project. During the war (1939-1945), the ancient epic virtually disappeared. The only production of note was the rarely seen British comedy Fiddlers Three (1943) starring Arthur Askey, which was very like Roman Scandals, and directed by the noted documentary specialist, Harry Watt.

The post-war period began with Gabriel Pascal's Caesar and Cleopatra, perhaps the most beautiful ancient epic ever photographed, and a thoroughly Shavian exposition of antiquity, filmed with George Bernard Shaw's full approval. Following the Berlin Airlift and the outbreak of the Cold War, the ancient epic resurfaced as a means of political discussion. Most ancient epics from 1948 to 1965, are at least to some degree a discourse on imperial power and its abuses, hence, Quo Vadis (Mervyn LeRoy, 1951), The Robe (Henry Koster, 1953), The Egyptian (Michael Kurtiz, 1953), Demetrius and the Gladiators (Delmer Daves, 1954), Ben-Hur (William Wyler, 1959), Cleopatra (Joseph L. Mankiewicz, 1959), Spartacus (Stanley Kubrick, 1960), The Fall of the Roman Empire (Anthony Mann, 1964) and many films developed on Grecian themes. An exception to the politicization of the ancient epic was the brilliant comedy A Funny Thing Happened 
to Me on the Way to the Forum (Richard Lester,1964).

Starting in 1955, with the release of Ulisse (Mario Camerini, 1955) in Italy, a new sub-genre appeared, the peplum or "sword and sandal" adventure film. From 1958-1964, nearly 200 of these low budget films were produced in Italy. Then they were abruptly superceded by the Spaghetti Western, and none were made between 1965 and 1983. The number of mainstream ancient epics also declined during this period, which nonetheless gave us such interesting pieces as Fellini's Satyricon (1969), Antony and Cleopatra (Charleton Heston, 1972), the British Broadcasting Corporation's television mini-series I, Claudius (Herbert Wise, 1976), Life of Brian (Terry Jones, 1979) and Caligula (Tinto Brass, 1979). With Sebastiane (Derek Jarman, 1984), there is the memorable appearance of what some critics have called the first unapologetically gay positive film.

The epic seemed to undergo a revival with The Odyssey (Andre Konchalovsky, 1997), Hercules (Ron Clements and John Musker, 1997), Titus (Julie Taymor, 1999), Cleopatra (Franc Roddam,1999), Quo Vadis (Jerzy Kawalerowicz, 2001), Alexander (Oliver Stone, 2004), Gladiator (Ridley Scott, 2000), Troy (Wolfgang Peterson, 2004) and 300 (2007), hailed alternately as the saviour or destroyer of the genre.

Serious critical consideration of the ancient epic only goes back about thirty years, to the pioneering identification, examination, classification and exposition of the genre and its sub-forms by Jon Solomon in 1977. Dr. Solomon, a classicist, informed his work with concerns and emanated from his work in classical studies 
and which echo many of the theoretical and aesthetic bases which underlie Baron von Gloeden's work. As a result, critical interrogations of the epic film have more usually been conducted by members or graduates of various university classics departments and programmes (Jon Solomon, Maria Wyke, Martin Winkler, Monica Silveira Cyrino), and the dialogue has been driven and focused by the primary concerns of classicism, i. e. authenticity and faithfulness to text. Jon Solomon's photographic captions for The Ancient World in Cinema often provide graphic expression of these concerns. The effect of these approaches is to establish and privilege the interpretation of the ancient epic primarily as an historical and ethnographic film. In his introduction to The Ancient World in Cinema, Dr. Solomon advances the classicist's pedagogical agenda, advocating the use of the classic film epic is an educational vehicle.

One can certainly enjoy film classics such as Ben-Hur...as 'pure entertainment,' but he should also be able to view them in light of ancient history and literature. Why? Because these films can be excellent entertainment, yet they can be so much more. ${ }^{5}$

While classicists embraced the ancient epic, constructing it as a vehicle for educating and reinterpreting history, film criticism has been very tepid in Its own reception of the genre and in giving serious consideration to its works. Indeed, it was not until 1977 that it was even recognized as a separate form, or congery of forms, and even that is attributable to the work of the classicist Jon Solomon. Because the ancient epic is considered scarcely a step above the crude and 
exploitative "sword and sandal" film it has seldom been subjected to serious critical enquiry and analysis. When film scholars have deigned to dirty their hands, it has most often been to look at Spartacus, probably because the stature of its director, Stanley Kubrick, lends it a cachet of seriousness, legitimacy and cultural acceptability.

The ancient epic exists as a frontier, remote from the centrality of critical focus, but laden with possibility. Neglected by most critics and theorists in film studies, the genre shows unexpected resonances when considered in light of Michel Foucault's pioneering work on sexuality, as well as Judith Butler's theories of gender, and the glosses by later critics Laura Mulvey, Steve Neale and Ina Rae Hark.

To accomplish this interrogation of this body of films, I propose to employ the critical approaches immanent in Gender Studies and Queer Theory, for an examination of non hetero-normative gender portrayals, the constructed nature of gender, and its performative nature, with reference also to Masculinity Studies. Queer Theory, in the instant discussion, offers approaches and insights which are not available in other theoretical models. These stem from Queer Theory's orientation to sexually oppressed minorities which have often been excluded from mainstream discourses. Marxist analysis, for example, has an economic bias, and for reasons of profit and production, is committed to hetero-normativity. An Auteurist approach is equally barren, as, despite its intrinsic allure, it offers no concrete methods of analysis. Even Masculinity and Feminist studies, while 
offering intriguing insights into the nature of male-female relationships and interactions, fail because of their primarily heterosexual orientation, to address the subtleties of homosexual systems of relationships, interaction and desire.

Michel Foucault's studies deal extensively with how gender is constructed by the individual, and the society around him, and its relationship to power and repression. Highly influenced by Louis Althusser's postulation of an ideological state apparatus, Foucault wrote The History of Sexuality, Volume 1: An Introduction in 1976 following his book-length examination of the mental health and (Madness and Civilization: A History of Insanity in the Age of Reason, 1961) and criminal justice systems (Discipline and Punish: The Birth of the Prison, 1975.) In the course of his studies, Foucault reexamined the concept of the ideological state apparatus, refining and extending it to the concept of sexuality itself. He established sexuality as an apparatus, suggesting that sexuality functioned in the same manner as church, state or family, and this critical interpretation of human experience, transformed the Althusserian hypothesis. Equally important is his suggestion that responses to an ideological apparatus could also be resistant, even seditious. As Foucault suggested, "there is a plurality of resistances, each of them a special case: resistances that are possible, necessary, improbable; others that are spontaneous, savage, solitary, concerted, rampant or violent; Still others that are quick to compromise, interested or sacrificial." ${ }^{6}$ It is this particular insight which is of greatest utility to this paper - that the response to social mechanisms has the potential to obstruct or impair or dislocate the 
functioning of that social apparatus, even as it may seem to be operating in concordance with it. Many films, which on cursory viewing and examination may seem to support and uphold conventional definitions and implementations of the masculine may, in fact, subtly question the nature and virtue of those definitions.

Foucault continued, introducing revolutionary interpretations of gender. He was among the first to suggest that gender is constructed in response to stimuli of the social system; that, indeed, it was not fixed or biological as had been previously thought, but was mutable and an artifact of various countervailing social influences. Men and women were no longer conceived of as defined or controlled by their genitals, but beings whose gender was established in response to many other stimuli, of which biological structure was but a single element. Foucault therefore eviscerated the Church's and the State's bases for the control and interpretation of sexuality and sexual beings.

There is no single, all-encompassing strategy, valid for all of society and uniformly bearing on all the manifestations of sex. For example. . to reduce all of sex to its reproductive function ... f fails to take into account the manifold objectives aimed for, the manifold means employed in the different sexual politics concerned with the two sexes, the different age groups and social classes. ${ }^{7}$

Basing her work on Michel Foucault's formulations of sexuality as cultural construction, Butler choreographed a masterly pavane of the pathways of gender formation and modification. For Butler, gender is a dance upon a bed of spikes. 
If gender is a kind of a doing, an incessant activity performed, in part, without one's knowing or without one's willing, it is not for that reason automatic or mechanical. On the contrary, it is a practice of improvisation within a scene of constraint. . . One is always 'doing' either with or for another, even if the other is only imaginary. But the terms which make up one's own gender are, from the start, outside one's self, beyond one's self in a sociality that has no single author and contests the notion of authorship itself. $^{8}$

Starting with Althusser's identification of sexuality as an instrument of social control, Judith Butler extended his work on two fronts: first, in examining the nature of gender production and definition; and second by elucidating Foucault's identification of the possible subversive nature of social compliance. Butler theorized that gender, in all its manifestations, was a performative activity to establish and convince others of an assumed gender rôle. Her discussion of the nature of drag illustrates the way in which all genders are formed and established, giving us a pattern against which to judge others' actions.

Drag . . . implies that all gendering is a kind of impersonation and approximation. If this is true, it seems there is no original or primary gender that drag imitates, but gender is a kind of imitation for which there is no original; in fact it is a kind of imitation that produces the very notion of the original as an effect and consequence of the imitation itself. ${ }^{9}$ Butler thus opened an elaborate lesbian-feminist discourse on the 
constructed nature of sexuality and its implications. While her primary focus has been as a lesbian, her insights have opened the way for further elaboration and discussion of the nature and place of masculinity and the male body. ... within the inherited discourse of the metaphysics of substance, gender proves to be performative - that is, constituting the identity it is purported to be. In this sense, gender is always a doing, though not a doing by a subject who might be said to preexist the deed. . . There is no gender identity behind the expressions of gender; that identity is performatively constituted by the very 'expressions' that are said to be its results. ${ }^{10}$ Steve Neale, in his essay "Masculinity as Spectacle," develops Butler's position and combines it with elements from Laura Mulvey's essay "Visual Pleasure and Narrative Cinema," on the nature of spectatorship and patriarchy, offering further insights into the positioning of the body as spectacle and forging a connection between Mulvey's pioneering feminist essay and studies of masculinity, specifically the representation of homosexuality: "Heterosexual masculinity has been identified as a structuring norm in relation both to images of women and gay men. It has to that extent been profoundly problematized, rendered visible. But it has rarely been discussed or analyzed as such."11 He argued that "male homosexuality is constantly present as an undercurrent, as a potentially troubling aspect of many films and genres, but one that is dealt with obliquely, symptomatically and that has to be repressed."12

Neale's work triggered an interest in films which placed the male body on 
show, and for reasons of historical custom and couture, this pointed to the ancient epic. Mulvey identified the nature of the cinematic gaze and spectatorship - that the point of view of the movie spectator is, and is crafted to be, that of a heterosexual male. The view therefore, is hegemonic - and yet, as Foucault has written, it may be something else also. In Hollywood films, spectatorship is constituted in a potentially dangerous and transgressive manner. As Neale posits in "Masculinity as Spectacle,"

The erotic elements involved in the relations between the spectator and the male image have constantly to be repressed and disavowed. Were this not the case, mainstream cinema would have openly come to terms with the male homosexuality it so assiduously seeks either to denigrate or deny. ${ }^{13}$

In particular, Neale looks at the nature of narcissistic identification and its relationships to power, control and aggression, which are also echoed in Ina Rae Hark's essay on Spartacus, "Animals or Romans." Mulvey established that the standard point of view of the spectator of the Hollywood feature film was that of the heterosexual male. This also applies to many nonHollywood films, in particular the epics which are subjects of the present discussion, as exemplified in Cabiria (1914) or Scipio l'Africano (1937).

While Neale, and Hark especially, argue that the spectacle of the male, the exposure to view of the male body objectifies, castrates and reduces the male to a 
similar position as woman in film, Neale expands upon this in his discussion of Paul Willamen's essay “Anthony Mann: Looking at the Male Body," in which he postulates that bringing the male body to view in the same manner as a woman's, stimulates homosexual desire, even in heterosexual males. This tension, he insists needs to be dispelled by removing the sexual attraction of the male body, usually by sado-masochistic display, hence the frequency of scenes of torture and bloody combat in the epic. By disqualifying the male body as an "object of erotic contemplation and desire" ${ }^{14}$ the epic discourse is made safe for patriarchal viewing.

Homosexuality is always a possibility, just beyond the edge of consciousness and can with surprising speed erupt and corrupt the unthinking heterosexual male. The very act of disqualifying the erotic potential of the male, is itself a process of uncertain value and result. Hark argues that this very process becomes itself an eroticization of the male. The performance of the male body portraying male undertakings and accomplishing stereotypical gender rôles is an erotically charged spectacle, which, rather than disqualifying the male as a sexual object, serves to underscore and emphasize his erotic desirability. This attempt to negate the naturally homosexual nature of masculine display acknowledges and stimulates the homosexual latency of the male and itself places in jeopardy the image of a conventional gender rôle, and by extension, the nature of patriarchal society itself.

Butler herself addresses this point in her own discussion of the bases for 
homophobia and homicide:

The desire to kill someone, or killing someone, for not conforming to the gender norm by which a person is "supposed" to live . . . is to court death. The person who threatens violence proceeds from the anxious and rigid belief that a sense of world and a sense of self will be undermined . . . . [V]iolence is a vain and violent effort to restore order, to renew the social world on the basis of intelligible gender, and to refuse the challenge to rethink the world as something other than natural or necessary. ${ }^{15}$

The problematic nature of cinema's response to, and relationship with, homosexual values and themes lies at the bottom of the ambivalent reception and utilisation of the epic genre. As dangerous as the epic may be as incipient threat to an insecure heterosexual society, it has been one of the most popular of entertainment venues, in that it allows a brief look at transgressive behaviors, allowing the spectator to savour the sweet taste of sin, then to be pulled back to safety and conformity before he or she became entirely mired in it. Further, most of the epics have been formed around Christianized stories of sacrifice. Thus, religion has taken control of the genre, and civilized it, turning transgression to its own purpose. Cecil B. DeMille was a master of this, creating representations of degradation and depravity and at the last moment snatching the spectator back and rewarding him or her with a satisfying religious experience. 


\section{Cabiria (1914)}

Cabiria is clearly one of the great films of Italian Cinema during the period 1905-1914. In point of fact, it is probably the best. It has stood the test of time and is admired both for what its director was able to accomplish, as well as for its influence on other directors and producers. Director Giovanni Pastrone used cutting edge technology and devised new shooting techniques. The results were so impressive that his work influenced Cecil B. DeMille, the American master of film spectacles, and also D. W. Griffith, inspiring his spectacular epic, Intolerance (1916). Cabiria also shows strong expressionistic influences, and Pastrone's Temple of Moloch is often cited as the the basis for the Heart Machine sequence in Fritz Lang's Metropolis (1927). Pastrone's use of location shooting, and free camera movement were shockingly modern, and anticipated some of the favored usages and approaches of the Neo-realist movement by nearly thirty years. The meticulous care in the preparation of sets and costume design set the standard for the big budget feature-length movies around the world. Even as rigorous and unforgiving a critic as Paul Rotha was impressed by the film.

... the most memorable is Cabiria, a classical theme from a scenario by Gabriele D'Annuzio. With its extensive cast and elaborate sets - such as, for instance the Temple of Moloch which anticipated Metropolis - this super production was a remarkable feat for $1913 .$. . $^{16}$ Bartolomeo Pagano, a dock worker from Genoa, became a star from his 
portrayal of the slave Maciste, one of the most complicated and conflicted representations of masculinity in the silent era. Over the next twelve years Pagano reprised his rôle in twenty-five films, always performing in full body blackface, as he did in Cabiria. Pagano was presented as clearly masculine: a very strong, muscular man, aged thirty-six at the time he starred in the film, although starting to bald. His costumes accentuated his chest, leg and arm muscles. His leopard skin sarong was never remotely transgressive or suggestive, but did seem to become slightly more revealing as the film progressed. Maciste is established as a stocky, physically active and competent man of great strength and endurance.

Maciste is frequently shown in profile or $3 / 4$ shots which display his great arm and chest muscles, while more distant shots explore the muscle development of his legs and calves. His image is clearly being developed to show strength, loyalty, tenacity and a particular type of non-ephebic male beauty. At the same time, the body make-up paints him as alien and exotic, so he is both exoticized and eroticized. One result of this, as Neale claims, is desensualisation through sadomasochism, and, indeed, Maciste is later captured, tortured and enchained. Neale insists that "We see male bodies stylized and fragmented. . . [in a manner]. . . designed to minimize and displace the eroticism they each tend to involve, to disavow any explicitly erotic look at the male body." ${ }^{17}$ Captured, Maciste is in a position of weakness, substantially eroding his existing portrayal as a source of strength, power and control. He is made powerless, and control is taken from 
him. He strength is re-appropriated to serve the interests of his opponents and new masters.

The scene in Bodastoret's tavern is certainly a major example of the power and complexity of Maciste's masculinity, as indeed, is that of his master, Fulvius Axilla, also. Maciste's masculinity is a delicately balanced opposition between dominance and submission. His physical strength alone is a mark of that dominance, yet out of loyalty and a sense of place, he is always available to act for Axilla (he is, after all, his slave). The tavern scene adds elements which make the construction of his masculinity more complex and problematic. His treatment of Bodastoret raises questions about the abuse of strength and power and whether limits should be set to the display of masculinity. As they visit the Carthaginian tavern, Axilla behaves in a conventional, non-threatening manner. He is quieter than Maciste who is rowdy, embodying the untamed male, with possibly a streak of homosexuality echoing Enkidu from the Sumerian epic Gilgamesh. Maciste's marked and continuing loyalty and passion stops just short of sexual fulfillment.

Pastrone clearly set limits to the expression of Maciste's loyalty and admiration, eliding the sexual potential of their relationship, in order to avoid confronting the transgressive, and further to construct Axilla's masculinity as a Roman or Fascist ideal. Maciste's strength and power is consistently on display as he and Fulvius Axilla (Umberto Mozzato) visit the Inn of the Striped Monkey. It is in later scenes, however, after the rescue of Cabiria (Lidia Quaranta)from the temple 
sacrifice, that Maciste displays himself in an overtly threatening manner. It is a display, moreover, which seems to place itself at odds with Neale's consideration of male spectacle. Maciste relies on his size and strength, which are markedly superior to the innkeeper's, to bully Bodastoret (Raffaele Di Napoli) into submission and coöperation.

Neale remarks critically on this phenomenon of male spectacle, where the male is put on exhibition, comparing it to the manner in which a woman might be exhibited in the traditional Hollywood film.

In heterosexual and patriarchal society, the male body cannot be marked explicitly as the erotic object of another male look: that look must be motivated in some other way, its erotic component repressed. The mutilation and sadism so often involved in [Anthony] Mann's films are marks both of the repression involved and of means by which the male body may be disqualified, so to speak as an object of erotic contemplation and desire. $^{18}$

Neale insists that the spectator is unable to accept any homosexual involvement, even one experienced vicariously through film. In his view this covert homosexual liaison threatens the spectator and must be neutralized. In the Hollywood film, there has always been a tension between the homosexual and an aggressive heterosexuality that feels threatened by alternative definitions or expositions of gender. It is within the ancient epic genre that this rises most clearly to the surface and can be most clearly viewed. It is Neale's view that the 
savage interaction which usually takes place within the ancient epic is a purgative which removes the threat of homosexuality by making the spectacular male unattractive through suffering and maiming. Yet is this so?

In Cabiria, graphic depictions of torture are avoided, and are only alluded to in the inter-titles. Maciste's punishment - being chained to a millstone - is clearly shown, and it is humiliating, but is it truly castrating as Neale seems to suggest? He is restrained and tortured by his jailers, then as a final punishment, he is chained to a mill stone and forced to labour on it. Yet, this does not seem to disqualify Maciste's strength and masculinity as Neale believes it should. Rather, the endurance of suffering and stoic behavior seems to have the very opposite effect of a performative enhancement and underscoring of his maleness. His time on the mill stones provides an opportunity for his muscularity to be on full display. Bodastoret shows, as he taunts the man, that he fears him still, even in restraint. Maciste's persona of the other, the dangerous other, is underscored and given full form and fulfillment in a later scene where Bodastoret is visited by Maciste, and he expires from fear.

We have here Foucault's theory of resistances at work. Is Maciste truly compliant as Althusser, perhaps, would suggest? Maciste bides his time. When Bodastoret visits him, to see if he is truly in chains, Maciste turns the tables and chases him around and around with the mill stone, terrifying him and showing that Maciste is, like Mt. Aetna, a power only waiting to erupt. Further, John Berger, in Ways of Seeing, suggests that the nude in Western Art is an idealized form. How 
could this be any different with the male, naked or semi-naked? The only cavil might be that of the heterosexist observer who is unable or unwilling to accept the idealized male. Ina Rae Hark writes that...

. . .the genre's cultural settings (biblical, Greco-Roman) allow for both male and female fashions that reveal considerable flesh; moreover in these cultures homo-erotic practices are widely acknowledged and the punishment of criminals or conquered is a highly elaborated public show, allowing for the ample spectacularization of male characters. Most frequently this spectacle is sado-masochistic, enacted through beating or torture, during which the male body, marked by punishment, is eroticized through stripping or binding. ${ }^{19}$

Cabiria is one of the earliest examples of sado-masochism invading the screen, ostensibly to purify the male body. The extremely virile Maciste is tortured in order to remove the potentialities of erotic gaze from his portrayals. As Neale remarks in his representation of Paul Willamen's work, "The repression of any explicit avowal of eroticism in the act of looking at the male seems structurally linked to a narrative content marked by sado-masochistic phantasies and scenes. ${ }^{20}$

But this violence is not a function of the film, but societal resistance, the resistance of the hegemony to a potential or perceived threat against its heteronormative standard. Film criticism will go on to elaborate this disjunction between homosexual and heterosexual desire, and the spectacle and the 
spectator in scenes of contest or struggle, especially in genres such as the Western, and in particular, variants such as Anthony Mann's films (1950's) or Sergio Leone's spaghetti westerns (1960's). The rôle of Messala, played by Francis X. Bushman in Ben-Hur continues this display of the strong, virile male, brutalized, ostensibly to remove his intrinsic erotic qualities, but often to an opposite effect. 


\section{Ben-Hur (1925)}

With the exception of the Fellini Satyricon and Sebastiane, Fred Niblo's Ben-Hur is one of the most erotically charged of all the ancient epics in terms of its exposition of male physicality and desirability. Its protagonists are with great constancy kept before us in poses and exempla of sexual attraction and gender performance that stress their male beauty and muscularity and establish them as objects of desire. Inasmuch as Ben-Hur is derived from a quasi-religious Christan novel, it is surprising that it is so egregiously transgressive.

Ben-Hur displays men in the manner that other films display women - as objects of erotic desire and possession. Laura Mulvey notes, in respect of the position of women in film that "In their traditional exhibitionist rôle women are simultaneously looked at and displayed with their appearance coded for strong visual and erotic impact."21 This objectification and commodification applies, with equal force and validity to the men displayed in the ancient film epic, and the character of Ben-Hur especially. The most erotically charged passage in Ben-Hur is that sequence which takes place below decks on Arrius' (Frank Currier) Roman galley. Male characters - the protagonist and the galley slaves are lightly clothed in ways which emphasize their masculinity, or its loss. Physically, the lack of clothing draws attention to muscle development and fosters and encourages desire for the male body. Yet at the same time, clothing, by its very absence, signals a degraded and debased social status. Given the 
realities of ancient costume, or rather the modern filmic expression of ancient costume, it is to be expected that many scenes would be dependent for their interest on revealing clothing which also clearly signals social position and rank.

The slaves are forced to perform harsh physical labour, and are whipped vigourously and frequently. Here is the desexualisation through sado-masochism that Neale proposes in "Masculinity as Spectacle." This is most especially evident in the below deck scenes on Arrius' slave galley. Here the slaves are stripped so they are nearly naked. Their bodies, glistening with sweat, are on display to whomever cares to look. Their will, their power, their individuality has been stripped away, emphasizing their weakness and powerlessness. Here, under the eyes and lash of the overseer, they are placed, unwilling on display. They become a spectacle for the viewer as well as the denizens of the plot. The attractive, heavily muscled male body of the the young slave hung naked on the bulkhead underscores the tyranny of the view. He is entirely and completely helpless to cover himself, to free himself or even to facilitate the spectacle of his body. For this man, ostensibly awaiting for, or recovering from the excess of the lash, Neale's problematic embrace of sado-masochism is a terrible reality. This treatment extends to Ben-Hur, who is condemned as a galley slave, and to Messala, who is severely injured in the wreck of his chariot. In these below deck scenes, Ben-Hur is not symbolically or physically castrated as Neale theorizes in his article, but instead show Neale's own "obsession with ...definitions of masculinity and masculine codes of behavior, and with images of male narcissism 
and the threats posed to it by women, society and the law. The threat of castration is figured in the wounds and injuries suffered. . ." ${ }^{22}$ Ben-Hur is given a temporary setback, a time of deprivation and loss, during which he husbands what few resources he may have, and prepares to reverse his fortunes when circumstances permit.

Novarro, as Ben-Hur is placed on show, and the spectators love it. He is a subject worth watching for his boyishness, his physicality and his pluck. He takes the path forward that Maciste took in Cabiria - reversal, loss, consolidation, restoration and redemption. Although Judah Ben-Hur is reduced to a slave, the scenes underscore his masculinity in two ways: first, in a physical manner through the use of revealing clothing, and second, it establishes strong male character traits, which Arrius recognizes, emphasizes, and rewards, as Roman. As Arrius inspects the rowers, he speaks with Ben-Hur, and is impressed by his responses and his spirit, which seem to him to be Roman. His defiance and thirst for revenge privilege him in the legate's eyes, and he is spared the chains when they engage the pirates.

For Ben-Hur himself, something quite different is in train. Unlike the slave boy suspended from the ship's bulkhead, Ben Hur retains a skimpy strip of cloth to cover his genitals, and he is only placed in the rowing benches. While chained in time of battle, the galley slaves would generally be permitted a limited amount of mobility, if only a respite from having their legs chained to their benches or their arms to their oars. Although for Ben-Hur, there remains a 
sado-masochistic threat, it is one which is never actually set in motion. Then, for Neale, Novarro remains fully eroticized and there is no no true attempt to subvert homosexual action or attraction: the male "body is feminized in these moments, an indication of the strength of those conventions which dictate that only women can function as the objects of an explicitly erotic gaze."23 But Neale's belief in a mandatory de-sensualisation of the male body is clearly not working in this film. Its major figures are both placed on display, and their sensuality is emphasized, not disavowed. The male body is treated in the same manner a a female body.

The Great Race sequence in Ben-Hur is one its most interesting and exciting parts, rivalled only by the naval engagement with the pirates and easily eclipsing it. The race gives us clear examples of Judith Butler's theories concerning the performativity of gender formation help to illuminate the ways in which both Ben-Hur and Messala strive against each other for mastery, revenge and power. Both men offer their bodies for display and viewing whilst engaged in exemplars of strength, skill, and masculinity. Each is an attractive physical specimen (Both actors had previously been employed as artists' models). Bushman is an older, more muscular male, intermediate between the youthful ephebic Novarro and the massive strength of Pagano's Maciste. The film produced an iconic still of Messala, one for which became the eternal memory and impression of Bushman - a profile shot, with hands on his hips, in his Roman costume. His head is thrown back in a proud and disdainful manner, summing up 
and encapsulating the image of the haughty Roman.

Butler's comments on gender ring especially true when linked to Bushman's exaggerated performance: "As in other ritual social dramas, the action of gender requires a performance that is repeated." ${ }^{24}$ She goes on to expand on this: "The effect of gender is produced through the stylization of the body and, hence, must be understood as the mundane way in which bodily gestures, movements, and styles of various kinds constitute the illusion of an abiding gendered self." 25

In Ben-Hur, there is a constant stylisation of the body of both stars. Each has constructed for himself a differing male gender performance, one which is in various degrees attractive to both male and female viewer. Novarro, as an example, is always dressed to show his well-shaped legs, while Bushman is posed to show his muscles and his profile. The Great Race sequences work especially well to present the two men in situations where they are able to clearly perform and establish their rôles in an atmosphere of contestation.

The race is a test both sexual and ethical. Messala and Ben-Hur are each put to the test, wherein each must perform feats of strength and masculinity in managing the four horse teams of the their chariots. The horses are strong, sleek and unruly, themselves icons of sexuality and masculinity, and it is necessary to bend their wills to the charioteer's. The horses are coded: Messala's are black and Ben-Hur's are white, clearly inscribing the race as a contest of good against evil. This contest becomes clearer when we see Messala 
resort to improper means to win. Ben-Hur on the other hand, becomes an exemplar of courage and moral conduct as he presses forward, fighting off Messala's whip attacks and, in wresting his penile whip away from him, symbolically unmans the Roman before defeating him.

Messala's conduct both before, and during the race is redolent of arrogance and ethical weakness. His companion Iras (Carmel Myers), the seductive Egyptian, daughter of Balthazar, in her degeneracy and decadence, spies on Ben-Hur, and tries to add him as a conquest when they meet at the tent of Sheik Ilderim (Mitchell Lewis). Ben-Hur, though tempted, spurns her and it is significant that as Messala is injured in the wreck of his chariot, she laughs uncontrollably. She acts as a herald of iniquity, embracing Messala, and tempting Ben-Hur. That she ensnares Messala but fails with Ben-Hur is a presage of Ben-Hur's own sexual and moral victory over the Roman.

As the race begins, Messala taunts Ben-Hur, "Scum of the galleys! I will grind you in the dust before all Antioch!" In the end, however, it is Messala who is literally ground into the dust. In his rage to win, he whips his opponents, crowds them and locks wheels with the chariot of the Greek, ruining it. He exhibits a highly questionable morality, which with his arrogance, thoroughly villainizes him. In contrast, Ben-Hur wins by being a better driver than the Roman, using his strength and ability to control his horses better than Messala, and wins fairly and without resort to cheating or bad behavior. His performance of masculinity involves skill, physicality, male beauty and moral superiority. He 
thus becomes both sexual and ethical model, a symbol attractive to all for a multiplicity of reasons. Following the race, Ben-Hur even continues to posture as a virile anti-Roman revolutionary, while the film moves to directly explore religiosity.

Ben-Hur presents an enchiridion of gender portrayal. Its variety, its vividity and its daring endow it with a power and charm which permits it to transcend time. The transgressive nature of male display, the naked slave boy on the galley, as well as the enactments of Messala and Ben-Hur, give the film an erotic quality within which its themes, characterisations and ritualized presentations look as fresh today as they did in 1925 . It is hardly surprising that the film antedates the appearance of the Motion Picture Production Code, which curbed many avenues of enquiry and exploration, even as it also opened other, more subtle forms of subversive treatment. 


\section{Sign of the Cross (1932)}

Although it would seem from production stills of Sign of the Cross, that it would be a significantly transgressive production, it is not so. There is a single scene in the second half of the film where Nero (Charles Laughton) appears on his throne with a muscular naked slave boy sitting at his right hand. While this is titillating and suggestive, no further advantage is taken of him, action initiated, nor even reference made to him. Yet the boy's positioning seems to subconsciously privilege the boy, at Nero's right hand, over his wife, who sits on his left. DeMille rewrites history, omitting any direct suggestion of Nero's well-known homosexuality, and his script transforms Nero into a henpecked husband, at the mercy of Poppaea (Claudette Colbert) deftly eliding her own meretricious origins while giving clear suggestions of her cruel and manipulative nature. Certainly there are a few very subtle suggestions, such as Laughton's overly langourous and aestheticized portrayal of the emperor, which effectively strip him of his power, allowing Poppaea to exercise a crypto-masculinity which controls and impels the emperor to follow her suggestions and accede to her will. Poppaea, then, becomes a figure constructed In the manner of male exercising effective power even as Nero is castrated and made subservient to his mistress. In the main, however, DeMille prefers to tempt his audience by throwing scantily clad young Christian girls to packs of ravenous alligators or lions for hetero-erotic effect. Sign of the Cross merely raises the spectre of homosexuality, to shock and horrify and 
perhaps terrify, then immediately rejects and denies it before it can gain any currency of expression or power. As Butler tells us, "Gender is the mechanism by which notions of masculine and feminine are produced and naturalized. Indeed, it may be that the very apparatus that seeks to install the norm also works to undermine that very installation."26

Poppaea is established in terms of conventional feminine spectatorship in the bath scene. Even so, DeMille raises the spectre of lesbianism and evil as Dacia (Vivian Tobin) joins her in the milk bath to spread gossip and assassinate character. Traditionally, lesbianism has been seen as less transgressive than male homosexuality, and is tolerated or ignored. In some venues, it is even encouraged as a stimulus for heterosexual males. DeMille even gives further free play to this erotic thread, permitting Ancaria (Joyzelle Joyner) to proposition Mercia. With Colbert's consummate acting skills, Poppaea is made an extremely attractive woman on offer to viewing males, and object of their desires. Yet she is simultaneously placed in direct opposition to Nero, who is clearly not an attractive male spectacle. DeMille risks the dissatisfaction of the Code administrators to place the Poppaean body on display; he does not act similarly for the Neronian one. Nero is disqualified by the corpulent actuality of his native form, not by any sado-masochistic device. Laughton is simply a physically unattractive male figure. The dynamics of the relationship between Poppaea and Nero well illustrate the thrust of Butler's argument above.

Sign of the Cross follows DeMille's characteristic directorial pattern of 
titillation and retreat into religious orthodoxy. During some of the arena scenes, he intersperses shots of a woman in the stands becoming sexually aroused by the carnage; Nero calmly eats grapes as men and women die before him. DeMille clearly has in mind the production of hetero-normative values, yet the material, and delivery which Laughton projects, and the presence of homo-erotic iconography, such as the slave boy, work against even this clearly purposed heteronormative piece, confirming Butler's asseverations.

Clearly, DeMille was informing his treatment of Neronian Rome with the wishes and standards of the recently enacted Motion Picture Code (March, 1930). The freedom and flexibility of action which Ben-Hur enjoyed were now gone, and in the new atmosphere was a much more conservative approach to gender and sexuality. Even so, DeMille's naked slave boy, Dacia's (Vivian Tobin) orgiastic dance, and Poppaea's bath scene all violate the code's prohibitions on complete nudity and undressing. The Code specifically cautioned against the depiction of base and sinful conduct: "No picture shall be produced that will lower the moral standards of those who see it. Hence the sympathy of the audience should never be thrown to the side of crime, wrongdoing, evil or $\sin .{ }^{\text {"27 }}$ While these scenes remained in the film, censors demanded that others be removed - dead bodies being carried from the arena in a cart, a gorilla dancing around a semi-nude girl, elephants stomping Christians and picking them up with their tusks, and one of crocodiles menacing a bound girl. With Sign of the Cross, despite some remnants of transgressive gender construction, we see the disappearance of truly 
questioning scenes and characterisations which will not return until William Wyler's remake of Ben-Hur and Stanley Kubrick's Spartacus in 1959-1960. Although DeMille's film contains several sub rosa presentations of gender subversion, it at least gives lip service to hegemonic practice. Yet, even in its final scenes, dominated by overpowering imagery of crosses, there is the barest suggestion of an abrogation of masculinity as Marcus Superbus (Frederic March), accedes to Mercia's (Elissa Landi) religious fervour and ascends the steps to the arena and martyrdom. 


\section{Spartacus (1960)}

Of all the ancient epics which have been filmed, Spartacus (Kubrick,1960) is the most problematic. At first blush, it seems odd that this is so, for Spartacus seems blessed with the talent of a number of competent actors - Peter Ustinov, Charles Laughton, Laurence Olivier; of an accomplished but blacklisted screenwriter Dalton Trumbo; and of a the well-established novelist, Howard Fast, who wrote the source novel. Further, the director is the talented and newly successful Stanley Kubrick. On paper, the film seems perfection, yet it is doomed by the stresses, both internal and external, of trying to serve both radically liberal and radically conservative ideologies simultaneously.

Spartacus is one of the best known examples of the Roman epic, and one which ranks high among the films produced during the decade of the 1950's. Few films are likely to approach or equal it in terms of recognition; it is possibly and very probably, the very best known of the ancient epic films. Spartacus differs from most ancient epics which are set in the time of Imperial Rome. Instead, this film is set in the time of the late Republic, during the Third Servile War, 73 to 71 BC, many years before the accession of Augustus. Thus it lacks a religious grounding such as is present in Quo Vadis, Sign of the Cross, Ben-Hur, The Robe, or Demetrius and the Gladiators. Facts were only a slight obstacle to the producers, however, who Christianized the film by crucifying Spartacus, an event which happened only in the imagination, and trying to portray him as a Christ-figure. 
Spartacus suffers from a number of conflicts in purpose and point of view, multiplied by personality clashes between the stars and the producers. Rights to Fast's novel were purchased by producer Kirk Douglas for his Bryna production company. Having been passed over for the starring rôle in Ben-Hur, he was determined to produce and star in his own ancient epic. Initially, he hired noted director Anthony Mann to direct his film, and hoped that accomplished actors such as Laurence Olivier would add a cachet of respectability to it. As a further aggravation, United Artists were preparing to produce a similar film about Spartacus, to be called Gladiator. Kubrick critic and biographer John Baxter sums up the relationship between producer and star Kirk Douglas, his director, and his actors.

Douglas preferred directors who said nothing and obeyed orders. Nor would Mann, who preferred understated performances, tolerate Douglas' overplayed acting. . . . (Mann later made El Cid and The Fall of the Roman Empire, regarded today as benchmarks of the genre for their visual style and understated playing.)

Douglas had other reasons to resent Mann. He felt the director was too friendly with the film's imported British stars, all of whom were scornful of Douglas' star status and bridled at his hectoring manner. ${ }^{28}$ The immediate source for Spartacus is Howard Fast's popular novel of the same name. Fast was a Communist, and he used his writing to establish Spartacus as an early fighter for workers' freedom against an oppressive oligarchy. Fast's 
novel had transformed Spartacus, the leader of the slave revolt, into a proletarian hero. The historical Spartacus seems to have been quite different from Fast's conception, and neither view of the rebel seems to have comported with Douglas' vision. Kirk Douglas, Spartacus' producer, was on the other hand, conservative, and Edward Lewis and Edward Muhl, producers and management at Universal, which funded the picture, were yet more conservative. This established a fundamental conflict of purpose between Fast's work and the production team. Douglas also hired blacklisted screenwriter Dalton Trumbo to work on the property, and although Fast and Trumbo were both Communists, each developed the story in a different manner. According to Kubrick biographer John Baxter, From the start, Douglas and Trumbo were at cross-purposes on the thrust of the film. Douglas, a passionate supporter of Zionism and Israeli independence, wanted what film historian Derek Elley called a "Roman variation on the let-my-people-go theme." Trumbo preferred to manufacture agit-prop for his own socialism. He played down Spartacus and emphasized Crassus, whom he used to parody the American military-industrial complex. ${ }^{29}$

As production continued, even more stresses appeared. Early establishing sequences shot by accomplished director Anthony Mann (fired because he was not as malleable as star/producer Kirk Douglas wished) remain some of the film's best moments. His replacement, Stanley Kubrick, was hired on three days' notice. Other scenes, featuring Laughton and Olivier are often cut short and stripped of 
significant motivations (c. f. Crassus' intimate relations with both Glabrus (John Dall) and Caesar(John Gavin)) as Universal sought to soften the film's effect on American moral sensibilities. The British actors formed a small clique, working together (with Trumbo and Kubrick) which Douglas perceived as a plot against him. With so many hands meddling with the broth, it is no surprise that the result is underdone and over spiced. According to Baxter,

Uneasily, Douglas began to realize that Kubrick was not the the tractable and grateful protégé he'd hoped for. This conviction hardened when he showed some rushes to Howard Fast. The novelist was delighted. How fortunate for Douglas to have found such a fine director on such short notice. Douglas was livid. Spartacus wasn't Kubrick's film, it was his. ${ }^{30}$ Against this confused background, the gender portrayals are equally unsettled. Spartacus (Kirk Douglas) is the central character in the film, yet the screenplay, and Douglas' acting, make him decidedly unsympathetic. He is constructed in an egregiously arrogant, heterosexual and ahistorical manner, falling in love with a fellow slave. When she bears his child, he becomes excessively sentimental. Kubrick even panders to this sentimentality giving us an extended scene showing Spartacus and his fellow gladiators wallowing in heteronormative satisfaction. In fact, the performances of Laurence Olivier and Charles Laughton are so good, and Kirk Douglas' so bad, that it is much easier to identify with them, although Olivier plays Crassus, ostensibly the villain. Inasmuch as most attention has been directed at the political allegories embedded in Spartacus, the 
nature of constructed genders for the film has been largely ignored, or treated from a cursory hetero-normative position. In this film, we encounter five characters with transgressive socio-sexual tendencies: Antoninus, Glabrus, Caesar, Draba and Crassus.

Yet, other than Crassus himself, these figures are rather poorly drawn, unhappily demonstrating that they are fictive straw horses and narrative fixtures used to establish the primacy of hetero-normativity and to underscore the innate depravity of Crassus and romanitas. Surprisingly, the best, and most interesting character development occurs in Draba (Woody Strode), the black slave who spares Spartacus in the gladiatorial combat and attacks his Roman masters, refusing to kill at another's command. Relying partially on image constructions from the popular 1950's plantation novels, Draba is a handsome and muscular black athlete, intelligent with strongly developed and expressed ethics, and an image of sexual desirability and insatiability. Even though this later characteristic is not allowed full reign, Claudia (Joanna Barnes) does express her barely concealed lust when she taps the "beautiful black one" to fight for her.

Fast and Trumbo play with a number of period stereotypes as they develop Draba's character including a sub rosa homo-eroticism implicit in the plantation novel, and more obvious, perhaps in that forum. In many ways, he is both a stronger, and better delineated character than Spartacus himself. He is clearly intelligent, which a strongly developed sense of self, and a moral code. He is developed in a sexually transgressive manner, but not in the same way as Crassus, 
or Antoninus, or the Roman generals in the film. The scene with Helena and Claudia raises the spectre of miscegenation, which was too terrifying for the audience to handle. Thus, Draba has to be killed, but in a way in which his moral development is heightened, in order to assist the basis of Spartacus' plot development, and in a way in which he is made a rôle model and object of multiplicative lusts. As he dies fighting the Romans, he is the perfect man, admired by both homosexual and heterosexual alike for his self assurance, competency and sexual attractiveness. He is sexually transgressive precisely because he, a black slave, embodies many Roman virtues: strength, intelligence, honour and, harking back to Ben-Hur, a thirst for revenge, values which we will see developed in Crassus.

Glabrus and Caesar are constructed as mere paper characters, ciphers who share sexual intimacy with Crassus and then seek advantage from his friendship (nominally heterosexual, they typify Roman sexuality and its omnivorous quality). They are used in the film to subtly blacken Crassus' reputation painting him as a pervert and libertine. The avidity with with they use sexual relationships for political advantage simply works to establish Crassus also as an opportunist, like them, and a man of questionable discernment. Antoninus (Tony Curtis) is a peculiar heterosexual creation, existing largely to fear Crassus' sexual advances. He is another one-dimensional character, and while his behavior sometimes displays feminine aspects, it is an illusion created to assist in the demonization of homosexuality, and Crassus, for Kubrick's audience. 
Yet Kubrick's film only seems to come alive in the person of Crassus, and Laurence Olivier's brilliant portrayal. Although meant to be a villain, Crassus transcends a problematic script and attains a true human stature. Crassus exemplifies a genuineness, even a nobility, which while not altogether palatable, is infinitely preferable to the vapid glibness and triumphant stupidity of other characters in the film. Crassus is clearly comfortable with a constructed homosexual gender totally at odds with 1950's convention. Charles Laughton's Gracchus presents a similarly comfortable, but hetero-normative construction, all the more interesting because the rôle is played by the homosexual Laughton. The finest portrayals in Kubrick's film are given by queer actors, even when playing heterosexuals; despite the overt intention of demonising Crassus, he is resistant to the effect. The clumsy expedient of manipulating prejudice is so out of touch with audience, script and actors, and Crassus' character is so finely developed, that the bugbear of homosexuality simply dissolves and melts away.

Spartacus, planned to be the hero, is a bit of worthless pasteboard. The reversal of rôles is surprising, and probably results from the internal stresses and tensions between the ultra liberal Trumbo and the more conservative director and producers. Whatever its causation, we look forward in glad anticipation and satisfaction to Spartacus' inevitable crucifixion. In the past, critics have largely been impressed by and come to grips with the political allegories implicit within the Spartacus narrative, addressing an Imperial America, the threat of cold war Russia, and the McCarthy persecutions. The only critic to significantly transcend 
these boundaries has been Ina Rae Hark, in her essay, "Animals or Romans." In this essay, she examines the dilemma of male subjectivity and spectacularization, with particular emphasis on power and powerlessness, and the tyranny of spectatorship and the gaze.

Looking at bodies, regardless of their gender, marks a principal form of control exercised in the discourses of institutional power that Michel Foucault has traced. In these systems where political control or subjugation intersect psycho-analytic models of subjectivity or lack, a male may very well find himself situated in positions analogous to that of the fetish or object of punishing voyeurism Mulvey describes as woman's in cinema's classic scopic regime. ${ }^{31}$

In the present film, it is the gaze that chains and restricts Spartacus' followers and ultimately prevents their attaining freedom or self actualisation. They are constantly under observation by their masters, either for pleasure, or because they are not to be trusted. The gaze serves the double purpose of solace and control. In Spartacus, everyone is subject to the tyranny of observation, even the Romans themselves. Gracchus is watched by Crassus, even as he himself is watched by Glabrus and Caesar. The gladiators fall under everyone's view, diegetic and non-diegetic, as they are scrutinized, disarmed, rearmed, defeated and killed. Crassus, in crucifying 6,000, grants them the very apotheosis of spectacularization. The rebels have been watched and denied, to provide an amusement for others, throughout their miserable lives. As they endeavor to 
break free, even as outsiders they are watched, pursued and watched, as they lie dead upon the field or hang dying on their crosses.

Gender portrayals are predominantly patriarchal. Other than the transgressive presentations previously catalogued, (those of Crassus and Draba, Glabrus and Caesar, and Antoninus) all establishing threats to the patriarchy, and which are all relatively minor in nature, all other gender performances (with the exception of Crassus) are hetero-normative. Gracchus, Varinia (Jean Simmons)and Spartacus are all clearly marked as heterosexual. The scenes delineating Spartacus' relationship with Varinia and his unborn son, are very sentimental and border on the mawkish. They certainly help illustrate the reason's for Anthony Mann's displeasure with Kirk Douglas' inability to deliver a subtle performance. In the end, it is Crassus, who as the villain of the peace should be reviled and detested, but who instead becomes grudgingly admired as human, though flawed. In this way we see yet again Foucault's theories of resistance and Butler's theories of gender performance flowering, against the intentions of the film's creators. Crassus' gender performances are entirely and totally transgressive, even as most others are purely patriarchal. Trumbo's script gave lip service to his employers' desires, and established Crassus' homosexuality. However, in complying, he also added a measure of subversive and resistant behavior. The personality of Crassus is highlighted and endowed with the simplest examples of genuine behavior, which rescue him from the dustbin of caricature. It is clear, from his scenes, that he is a sincere patriot, which gains our respect, and when he 
looks after Varinia, that he also has the ability to care for others. He is yet another of the strange litany of contradictions which give Spartacus its unsettling feeling. Though he is gay, his active and unapologetic sexuality negates neither his authority nor his capabilities, which would have been expected in a film of this period. Instead, he is unwittingly established as a powerful, although homosexual, male.

In Spartacus, Stanley Kubrick tries to subvert the conventions of the epic, and instead gives us a production which is plagued with questions of identity and intention, one abounding in crude manipulation of the viewer, gratuitous violence, and a confusion of purpose. Employing patriarchal gender performances, and a few examples in which aberrant sexuality is raised only to be immediately disqualified and rejected, the film permits only one truly transgressive performance, that of Crassus, who the film patently attempts to diminish and denigrate, but who is instead established as a sympathetic character, in spite of the film, further adding to the confusion and disorganisation which mark the film. 


\section{Fellini Satyricon (1969)}

By far the most innovative and successful of the ancient film epics is Fellini's creative transcription and adaptation of Petronius' fragmentary novel, the Satyricon. The original extent of the Petronian work is unknown, although it must have extended to multiple volumes, and it has been suggested that it may have had a length comparable to Marcel Proust's À la recherche du temps perdu. It survives today only in a few fragments amounting to 141 chapters, assembled from two major sources and smaller bits found scattered in other manuscripts, or sometimes as quotations in other authors. These allow us to see the author's textual virtuosity and scathing humour. Highly sexual in nature, the Satyricon for many years presented a challenge to academics who recognized the brilliance of its writing, but blanched at the themes and open discussion of subjects conventionally ignored.

Because of this erotic aspect, and the manner in which Fellini presents it, the work can arguably be said to be one of the first gay positive films, a palm usually given to Derek Jarman's Sebastiane (1984). The early opening scenes of the film, show the two lovers Encolpio (Martin Potter) and Ascilto (Hiram Keller) in semi-naked erotic embrace and struggle. As they fight over the boy Gitone (Max Born), the film not only fails to condemn or criticize their sexuality, but in fact confirms and ratifies their homosexuality as natural and acceptable, inviting the spectator to join and experience their passion. It is clear from the staging that the 
two have been, and may even still be, in love, for they have that special ability to infuriate the other which is the residue of passion and familiarity. The very choice of actors, Martin Potter and Hiram Keller, further confirms and supports this view, as they are both exceptionally attractive, muscular and physically desirable young men (Keller was a professional model nicknamed "The Face.") Fellini himself remarked that "Because of the picture's open, non-judgmental portrayal of homosexuality, some journalists seized upon the tempting notion that I myself must be a homosexual or at least bisexual...."32

In many ways, Satyricon exhibits the influence of Jean Cocteau (1889-1963). Fellini's otherworldly, surrealist quality is substantially the same as that with which Cocteau imbues his major films: the Orpheus Trilogy (Le Sang du Poète (1930), Orphée (1950) and The Testament of Orphée(1960). The unstructured and erratic nature of the plot, the establishment of a fantasy worldscape, and the use of exaggerated characterisations capture much of the feeling of Cocteau's surrealist films and the surreal quality implicit in Petronius himself. Giovanni Grazzini, writing in the Corriere della Sera considered that

Fellini's Rome bears absolutely no relationship to the Rome we learned about in school books. It is a place outside historical time, an area of the unconscious in which the episodes related by Petronius are relived among the ghosts of Fellini... His Satyricon is a journey through a fairytale for adults. It is evident that Fellini, finding in these ancient personages the projection of his own human and artistic doubts, is led to wonder if the 
universal and eternal condition of man is actually summed up in the frenzied realization of the transience of life which passes like a shadow. ${ }^{33}$ Perhaps "fairy tale for adults" is a proper description of the Petronian canon. It is a phrase which also brings to mind Cocteau's own La belle et la bête (1946). There is a surreal quality to the Latin original which Fellini has captured rather well. In Comments on Film, he expressed this surrealist intention “. . .to eliminate the borderline between dream and imagination: to invent everything and then to objectify the fantasy; to get some distance from it in order to explore it as something all of a piece and unknowable." ${ }^{34}$

The result then, in a manner horrific to the classicist, yields a remarkable artifact, a recreation of the spirit of Petronius' Rome, but without its physical or visual simulacra. Further, it exhibits and explores Roman sexuality, in a way unthinkable in conventional form. Roman sexuality was quantitatively and qualitatively different from present day social norms. In Rome, it was not the type of sexual activity that was the preeminent concern, but the rôle and position of the participants. It was permitted for the Roman male to have sex with slaves, free persons, even animals of either sex, but it was of paramount importance that he not be penetrated by a slave or animal, by another male generally, which would be the vilest type of immorality. Lesbianism, although generally ignored, ranked as an abomination of equal weight. Nonetheless, there are allusions within the film to a multiplicity of sexual activities, and Petronius is always alarming, amusing, and ribald. 
In order for the film to be more easily produced, it was necessary for Fellini to reconceive the nature of the work, not a simple task. An indication of the nature of the challenge may be gained by recalling that his rival, Gian Luigi Polidoro, was prosecuted for obscenity for his version of the Satyricon. As Fellini biographer Hollis Alpert notes:

The completed screenplay envisioned the film as a large and incomplete mosaic, or, as put yet another way by Fellini, a series of frescoes, loosely tied together by the adventures of Encolpio and Ascylto, and their rivalry for the affections of the boy, Gito. The nearly five hundred page script, larded with precise descriptions of every prop, costume and background, was made up of nine major sequences broken into sixty-eight scenes. Fellini then had the enormous task of translating his dreamlike and often nightmarish vision of the world of decadent Rome onto film. ${ }^{35}$

Classical scholar J. P. Sullivan notes that Fellini was induced to supplement the existing text with material from Petronius' contemporaries, Juvenal (Satires 3.193196), Martial (Epigrams 3.93) and Apuleius (The Golden Ass) are specifically mentioned. As he also noted in his essay "The Social Ambience of Petronius' Satyricon and Fellini Satyricon,"

Fellini Satyricon (1970) has proved something of a puzzle to some critics, whose reaction to the film can hardly be construed as favorable. Classical scholars have been particularly troubled by its syncopation of events, its drastic redistribution of events among the characters, and above all, its 
non-Petronian sources...I shall argue that Fellini, faced with the battered torso of this ancient novel, with only a tenth or twentieth of it still extant, felt justified as a director and creative translator to supplement the fragmentary narrative with incidents and details from more or less contemporary literary and historical works. ${ }^{36}$

Fellini chose a very different path to recreate the ancient world. He did read extensively on Rome in the time of Nero, but he made no overt effort to make a perfect simulacrum of the time, as other directors had done. He preferred to establish a dream world which was imbued with elements and the flavor of the classical world. As he noted in I, Fellini

Scholars all over the world would be comparing Fellini and

Petronius. Being too imaginative can be a greater fault in the eyes of the critics than being too prosaic. I can work only to please myself and share my dreams, so I have to shut out the critics as best I can. ${ }^{37}$

His was the final blow which vanquished the rule authenticity in the cinematic representations of the ancient world. Henceforth, recreations of plot and mis en scène would be freer, but with a due regard for historical correctness as or where appropriate. We see echoes of this in Gladiator, where the script very clearly plays fast and loose with historical accuracy, even as the mis en scène is often a faithful, but not too faithful, recreation of Roman monuments. In following this approach, Fellini produced one of the most evocative classical epics. Fellini openly grapples with transgressive sexuality: Ascylto tells us he has 
been a prostitute; Gito's actions suggest he is little different; one of his characters is an hermaphrodite; aboard ship, Lichas tries to marry Encolpio; Ascylto and Encolpio have relations with an African slave girl, and each other at the villa of the suicides; Encolpio is unable to effect an erection, and is ridiculed for it. It is a picaresque tale in which Fellini saw "parallels to modern society." 38

Gito's character is marked by an adaptable fickleness. He imbibes sex with a sang-froid that underscores his opportunistic and meretricious nature. He does not deserve the affection of either Ascylto or Encolpio. Ascylto seems drawn to Gito simply for his utility as a sexual toy. He uses people, such as the black slave girl in the suicide sequence, as things to give him pleasure. Encolpio, though perhaps truly caring for Gito, is so self centred that Gito turns to Ascylto. Encolpio has been cursed by the god Priapus for violating his temple, hence the sexual nature of his torment and punishments.

If there is any moral in Petronius, it is that a graceless life is one of horror. Life should be lived joyously, deliberately and with due care. A good life is an elegant one, and in the Satyricon we see mock elegance at every turn, and its catastrophic heritage. In bringing the Satyricon to the screen, Fellini also opened a discourse on the corruption in modern life which is paralleled by the corruption in ancient life. His sexual athletes are condemned, not for their homosexual or bisexual nature, but for their lack of charity, and their crassness, the most stunning example of which is the death of Ascylto, who is killed by a boatman, as Encolpio ignores him and undertakes a cure for his impotence. 
Fellini's work with the transgressive sexuality of Petronius has been very courageous. While critics might blanch and complain, he has embraced the world of alternative sexual identities, and proclaimed them to be quintessentially human. Fellini does not attempt to construct a patriarchal image of gender or sexuality, as Cabiria does. Alternative sexualities are not hidden, as in Ben-Hur, nor are they portrayed as evil, as Spartacus attempts. He does not establish his film as a vehicle for hetero-normative portrayals. Heterosexual behaviors are shown as simply one of many possible choices or pastimes. In establishing an ethical standard for his work, it is not sex or sexuality which is the determinant, but rather the moral choices made by the individual. In Fellini, transgressive gender has become a non-issue. 


\section{Gladiator (2000)}

Ridley Scott's Gladiator is not a film which turns over new ground, but rather plants its seed in existing plots of historical genre and circumstance. In many ways it follows the themes developed in Spartacus, but it demonstrates a far greater finesse, and, what is, perhaps, its greatest strength, a coherent sense of plot and purpose. Its greatest weakness, on the other hand, is its ponderous pacing. It is tendentious and tiring. A second strength is the aesthetically pleasing cinematography, far more elegant and expressive than Kubrick's, with greater depth and aesthetic development. Cinematographer John Mathieson's impressive camera work is suggestive of the Fellini Satyricon. Ridley Scott clearly learned and benefited from the forty years that transpired since the making of Spartacus, allowing his cinematographer, Mathieson, the freedom that Kubrick denied his cinematographer, Russell Metty.

It is clear that Gladiator began with Spartacus' basic structure, then reestablished it in a different time period, one more congenial to the ancient film epic. Most ancient epics take place during the period of Imperial Rome, rather than Republican Rome, if for no other reason and purpose than to use the Emperor as a plot heavy. Sign of the Cross immediately commends itself to our attention as an example of this as well as Quo Vadis (1951) and its associated films of the 1950's, The Robe (1953) and Demetrius and the Gladiators (1954). Even the character of Draba (Woody Strode) is brought across in Gladiator, this time 
renamed Juba (Djimon Hounsou), just as General Maximus Decimus Meridius (Russell Crowe) replaces Spartacus (Kirk Douglas). It is, nonetheless, more highly fictive in nature than Kubrick's Spartacus, presenting us with an alternative reality apparently based upon the conspiracies of 182 A.D. In the process, Gladiator produces an strong and powerful film narrative: well wrought, intelligent and coherent. In all ways, the changes are improvements. It is the inordinate attention paid to this narrative, however, that creates much of the ponderous nature of the film.

While Gladiator's plot seems to be somewhat byzantine, in actuality, it is a simple story of revenge, set with a few subplots which give the impression of greater complexity: there are The Emperor, Marcus Aurelius' (Richard Harris) Death, Maximus' Lust for Marcus' daughter Lucilla (Connie Nielsen), and The Quest for the Restoration of the Republic, but the primary motive, and the primary action revolve around the general's desire to kill Commodus (Joaquin Phoenix), the cause of his family's suffering and death. As Marcus Aurelius oversees battles on the German frontier, he confesses to Maximus that he is ill and dying. He calls him the son he should have had, and secures a pledge from him to be his executor, returning power to the Senate. He specifically names Commodus a moral failure, unfit to rule. Commodus is keen to secure power, and when he is told he will not receive it, he crushes his father in his arms, killing him. He seeks Maximus' loyalty, but it is denied, and he orders him, and his family, killed. Maximus is a bit put out by Commodus' condemnation and kills the detail assigned to despatch him. He 
rides for his family's farm but arrives after Commodus' men have done their work. He buries his wife and son and collapses, exhausted. This is perhaps the weakest point in the plot, as he is picked up by brigands and sold into gladiatorial service. As a gladiator, Maximus quickly shows his ability as a killer, impressing his master, Proximus, a retired gladiator himself. Eventually Proximus is offered an opportunity to provide men for the Coliseum, and they head to Rome. Maximus becomes a great favourite in the ring, meeting Commodus who is greatly displeased by his survival. Marcus Aurelius' daughter Lucilla, object of Commodus' lust conspires with Senator Gracchus (Derek Jacobi) to depose Commodus and restore the power of the Senate. Initially dismissive, Maximus finally joins their conspiracy. They are discovered, Gracchus imprisoned, Lucilla forced into concubinage with Commodus and Proximus is killed. Commodus visits Maximus and arranges to fight him in the arena. He prepares for the contest by stabbing Maximus in the shoulder with a poisoned dagger.

Expecting an easy victory, Commodus is disconcerted and discomfited by Maximus' stamina. He fights, wounds Commodus, and then proceeds to hold himself together with sufficient strength and determination to kill him. Reeling from the dagger's effect, he arranges the release of all prisoners, including Gracchus, and urges the restoration of the Senate, before he dies and joins the shades of his wife and son.

Gladiator was received like a long lost child by the community of classical scholars. It was praised extravagantly by the usual commentators - Jon Solomon, 
Martin Winkler and Monica Cyrino. Cyrino offered the observation that although it is considered a derivation of Spartacus, there is important contextual material originating in Anthony Mann's The Fall of the Roman Empire (1964), specifically the life Commodus, and Ben-Hur and its thirst for revenge, She further discusses the similarity

In this, he resembles Judah-Ben-Hur in William Wyler's Ben-Hur (1959), who is driven by his bitter quarrel with the Roman tribune Messala, once his intimate boyhood friend. Like Maximus, Judah is brutalized and enslaved by the Roman system, loses his family and seeks vengeance against the man who had injured him and them. Both heroes play out their personal revenge in the arena in scenes of extreme violence which show not a shred of forgiveness. ${ }^{39}$

As Jon Solomon notes, screenwriter David "Franzoni is not a classical scholar. He is a story teller capable of finding inspiration in historical sources and adapting them for the screen." ${ }^{40}$ In typically classic fashion, he also criticizes the opening battle: "And while authenticity and plausibility - cavalry in a forest battle? - are questionable, such free invention makes for thrilling footage." ${ }^{41}$ Together, the classicists rehash their old concerns about authenticity and political allegory, and apply them to the new film. To be fair, Gladiator is replete with political allegory not seen since the 1960's. The choice of the Emperor Commodus for villain can hardly have been accidental. His reign was marked by cruelty and 
paranoia, which was finally ended when conspirators arranged to have him strangled in his bath in 192 AD. The Roman historian Dio Cassius notes that This man [Commodus] was not naturally wicked, but, on the contrary, as guileless as any man that ever lived. His great simplicity, however, together with his cowardice, made him the slave of his companions, and it was through them that he at first, out of ignorance, missed the better life and then was led on into lustful and cruel habits, which soon became second nature. And this, I think, Marcus clearly perceived beforehand. Commodus was nineteen years old when his father died, leaving him many guardians, among whom were numbered the best men of the senate. But their suggestions and counsels Commodus rejected. . . . ${ }^{42}$

If anything, Gladiator somewhat softens this view of the emperor, yet the warning about selfish, inconsiderate and incompetent political leaders remains clear. (Like Roman society, American society faced an imperial threat which became chillingly real in the years following Gladiator's release). The film was not a complete success in its home market release, however. Most of its box office came from foreign showings. Populist critics were evenly divided between worshiping the film, and panning it. The internet was rife with amateur reviews.

Gladiator is a relatively conservative creation with respect to gender construction. There are a handful of scenes which suggest, or even overtly show non-conforming material. As the Praetorian Guard comes to arrest Senator Gracchus, an effeminate slave boy alerts him to their presence; he is exceptionally 
well dressed and well groomed, his hair specially coiffed and his eyebrows emphasised, suggesting a possible homosexual relationship or service to the Senator. Commodus' associate Cassius (David Hemmings) is drawn in an ambivalent manner. His use of a curled wig may be suggestive of some form of a transgressive sexuality, but it might also be simply stage dressing for his work at the Coliseum. Both of these non-conforming gender portrayals are highly subjective, and difficult to quantify. That they may illustrate an eunuchal or homosexual nature probably more accurately reflect a DeMille type titillation and withdrawal tactic deployed by the producers, than any truly transgressive sexuality.

Most interesting perhaps is the thread linking Maximus, Lucilla, and her son Lucius. Lucius' father - Lucius Verus - was a close friend of Maximus, possibly, though uncertainly, his lover. The film, while allowing for the possibility of such a relationship, instead suggests a more hetero-normative one between Maximus and Lucilla. Yet Maximus' regard for the young Lucius, and his almost paternal relationship with Lucilla, argue for an intensely personal relationship. Further, at one point he discusses the elder Lucius with Lucilla, and his reticence and wistfulness support a relation of greater depth than friendship.

Further, the projection of inter-gladiator relationships walks a fine line between homo-social and homo-erotic. In several cases, between Juba and Maximus and Maximus and Tiger (Sven-Ole Thorsen), the relationship seems poised to move to a physical one, but this never happens. At one point Maximus engages 
in a serious discussion with Juba about their families, and there seems to be an informal, unstated possibility of a more intimate connection, and, once again, in a discussion with Tiger, yet in neither situation is there a progression to physical interaction. The writers are masters of titillation and withdrawal, echoing DeMille's style. Generally, though, Maximus is presented in relationships with other gladiators in such a way as to suggest that sex does not come into play. Most character interactions are formed to a patriarchal, hetero-normative standard. The only relationship with homo-erotic overtones, is that between Maximus and Marcus Aurelius' son Commodus. Is it there? Is it imagination, or is it a transgressive suggestion planted only to be rooted up if it begins to sprout leaves and prosper, as has so often happened before with previous examples of this genre? Commodus seems to want them to be friends, or to gain Maximus' support, rather than his opposition. Commodus explains their closeness, as that of brothers, springing from Maximus' relationship with Marcus Aurelius. This seems quite plausible, but to make the relationship somewhat murky, Commodus is portrayed in a manner showing his spite, his duplicity, his cruelty and his cowardice, which are often traits associated, at least in hetero-normative films, with homosexuals. Yet, as he speaks with Maximus before they fight in the arena, he says "You loved my father, I know. But so did I. That makes us brothers, doesn't it? Smile for me now, brother." [stabs him] That act seems to disqualify an erotic relationship with Maximus. He seems simply to want an incestuous relationship with his sister. While Commodus' sexuality is distinctive and illicit, it certainly is not pushing the 
boundaries of gender formation, and indeed, the film as whole has very little to do with a transgressive sexuality, other than the casting forth of DeMille-style red herrings.

Gladiator gives us very little in the way of concrete expressions of transgressive gender formation - a few suggestions, perhaps, that are immediately disallowed, hints that are immediately undercut, and stray indications which are nowhere integrated into the script or mis en scène. It is a conservative's take on the Empire, as might well have been commissioned fifty years before, in the time of Senator McCarthy. 


\section{Conclusion}

With the dawn of the twenty-first century, we see that filmmakers are still following the path originally blazed by Baron von Gloeden: the use of classical elements to make the unpalatable palatable and acceptable. Film directors, following von Gloeden, established a tradition of homo-erotic gaze and masculine appreciation within the form of the ancient Graeco-Roman film epic. Judith Butler argues that by clarifying issues of power and identity, the homo-erotic defines and strengthens heterosexual identity. Representations of the male body and the nature of the homo-erotic gaze probe the inner tension created by male homoerotic expression in the filmic text and societal demands for hetero-normativity.

In the films examined, Cabiria is primarily patriarchal, but it is constructed in a manner by which the new Italian man is established and displayed in a sexually attractive manner. Ben-Hur follows during a period when transgressive representations are most freely permitted, and presentations of the male body as an attractor abound, including full nudity. Sign of the Cross, though patriarchal, still exhibits a few queer gender presentations in defiance of the Motion Picture Production Code. During the Cold War, Spartacus tries to establish heteronormativity, but instead presents us with startlingly positive images of the homosexual, and surprisingly negative impressions of the hetero-normative. Satyricon, produced in Italy, surprises us even more as Fellini presents transgressive gender constructions in an open and non-judgemental manner. The 
morality of his characters is clearly not a function of their sexual choices. In its latest cycle, the ancient epic is remarkably similar to the films of the 1950's: conservative and political. Gladiator's warning of the danger of an imperial presidency is little different from Spartacus' of an imperial USSR. However, for Gladiator, the construction of gender is almost entirely hetero-normative, with homosexuality only hinted at.

Baron von Gloeden's thrust was physical and sexual; his boys became eroticised ideals of male beauty, incarnations of the Other clothed in a legitimating garment of ancient history, art and literature. Today, nude photography, especially male nude photography, has a degree of acceptance unheard of and unthought of in his own time. Yet von Gloeden's approach to transgressive behaviour and art remains valid, even today. Robert Mapplethorpe in particular, has used von Gloeden's approach, and combined it with new points of view and racial exposure to establish another transgressive view of the male body which disturbs even today. That exhibitions of von Gloeden's work have occasionally been censored, which merely reinforces and underscores the resistive nature of his work.

Roland Barthes characterised his work thusly: ...von Gloeden worked untiringly to produce this mixture [Barthe considers von Gloeden's work kitsch] without having to think about it. From that emerges the power of his vision, which continues to astonish us even now: his naivetes are as grandiose as his skills. ${ }^{43}$ In the epic, even in incarnations which were conceived as patriarchal and 
hetero-normative works, small, and sometimes large bits of transgressive gender formations appear. It is a fact that can not be completely dismissed. While deploying elements of von Gloeden's transgressive approach, many overtly hegemonic films still reveal the existence of resistive structures within the narrative. Cabiria, Sign of the Cross, Spartacus, and Gladiator, which especially tries to avoid any homoerotic situations, show evidences of transgressive gender formations. Other films, such as Fellini Satyricon and Ben-Hur, in their very transgressiveness act to give definition to hetero-normatively as Butler has claimed. These particular films result in the the most favorable and positive depictions of heterosexual gender formations.

Heterosexuality and homosexuality, and myriad intermediate states, are a part of the human condition, and will not be disallowed. Epic directors have sometimes consciously, sometimes unwittingly and sometimes cynically followed in the Baron's footsteps. The use of classical imagery and aesthetics still serve to clothe and make more acceptable images sexually and politically transgressive. In the words of the old French proverb, Plus ça change, plus c'est la même chose. 


\section{Endnotes}

1 Jack Woody, ed., Taormina: Wilhelm von Gloeden. 3rd ed. (Santa Fe: Twelvetrees Press, 1997), n. p.

2 Ibid.

3 Judith Butler, Gender Trouble (New York: Routledge, 1990), 77.

4 Monica Silveira Cyrino, Big Screen Rome (Oxford: Blackwell Publishing, 2006), 1.

5 Jon Solomon, The Ancient World in Cinema (New York: A. S. Barnes, 1977), 9.

6 Michel Foucault, The History of Sexuality Vol 1, The History of Sexuality: An Introduction (New York: Vintage Books, 1990), 96.

7 Ibid., 103.

8 Judith Butler, Undoing Gender (New York: Routledge, 2004), 1.

9 Judith Butler, "Imitation and Gender Insubordination" in Inside/Out: Lesbian Theories, Gay Theories ed. Diana Fuss (London: Routledge, 1991), 21.

10 Butler, Gender Trouble, 24-25.

11 Steve Neale, "Masculinity as Spectacle"in Screening the Male, ed. Steven Cohan and Ina Rae Hark (New York: Routledge, 1993), 9.

12 Ibid., 14.

13 Ibid., 19.

14 Ibid., 14.

15 Butler, Undoing Gender, 34.

16 Paul Rotha and Richard Griffin, The Film Til Now (London: Spring books, 1967), 323-324.

17 Neale, 18. 
Ibid., 14.

19 Ina Rae Hark, "Animals or Romans" in Screening the Male ed. Steve Cohan and Ina Rae Hark (New York: Routledge, 1993), 151-152.

20

Neale, 16.

21 Mulvey, 10.

22 Neale, 15.

23 Ibid., 18.

24 Butler, Gender Trouble, 140.

25 Ibid.

26 Butler, Undoing Gender, 42

27 Leonard J. Jeff and Jerold Simmons, eds., "The Motion Picture Production Code of 1930" in The Dame in the Kimono: Hollywood, Censorship, and the Production Code from the 1920s to the 1960s (New York: Grove Wiedenfeld, 1990), 286.

28 John Baxter, Stanley Kubrick: a Biography (New York: Carroll and Graf, 1997), 127.

29 Ibid., 133.

30 Ibid., 136.

31 Hark, 151.

32 Charlotte Chandler, I, Fellini (New York: Random House, 1995), 172.

33 Claudio G Fava and Aldo Vigano, The Films of Federico Fellini (New York: Citadel Press, 1990), 135.

34 Federico Fellini, Comments on Film, ed. G. Grazzini, trans. Joseph Henry, Fresno: California State University, 1988, 173.

Hollis Alpert, Fellini, A Life (New York: Atheneum, 1986), 206. 
36 J. P. Sullivan, "The Social Ambience of Petronius' Satyricon and Fellini Satyricon" in Classical Myth and Culture in the Cinema, ed. Martin M. Winkler, (New York: Oxford University Press, 2001), 259.

37 Chandler, 172.

38 Alpert, 195.

39 Monica S. Cyrino, "Gladiator in American Society," in Gladiator: Film and History, ed. Martin M. Winkler, (Oxford: Blackwell Publishing, 2004), 132.

40 Jon Solomon, "Gladiator from Screenplay to Screen" in Gladiator: Film and History, ed. Martin M. Winkler, (Oxford: Blackwell Publishing, 2004), 2.

41 Cassius Dio, History of Rome Vol. IX, trans. Ernest Cary and Herbert Foster (1927; repr., Cambridge: Harvard University Press, 1969), 73.

42 Woody, n. p. 


\section{Selected Bibliography}

Alpert, Hollis. Fellini, A Life. New York: Atheneum, 1986.

Arenas, Amelia. "Popcorn and Circus: Gladiator and the Spectacle of Virtue." Arion: A Journal of Humanities and the Classics 9, no. 1 (2001): 1-12.

Bankston, D. "Veni, vidi, vici." American Cinematographer May 2000: 46-53. . "Death or Glory." American Cinematographer May 2000: 41-45.

Dio, Cassius. History of Rome. Translated by Ernest Cary and Herbert Foster. 9 vols. Loeb Classical Library. Cambridge: Harvard University Press, 1927.

Rhode, Eric. A History of the Cinema from its Origins to 1970. New York: Hill and Wang, 1976.

Bazin, André. What is Cinema? Translated by Hugh Gray. Berkeley: University of California Press, 1967.

Baxter, John. Stanley Kubrick: a Biography. New York: Carroll and Graf, 1997.

Berger, John. Ways of Seeing. London: Penguin books, 1977.

Butler, Judith. Gender Trouble. 10th Anniversary Edition. New York: Routledge, 1999.

- Bodies that Matter: On the Discursive Limits of Sex. London: Routledge, 1993.

- Undoing Gender. New York: Routledge, 2004.

Cantarella, Eve. Bisexuality in the Ancient World. New Haven: Yale University Press, 1993.

Chandler, Charlotte. I, Fellini. New York: Random House, 1995. 
Cohan, Steven. "Masculinity as Spectacle" in Screening the Male: Exploring Masculinities in Hollywood Cinema. ed. Steve Cohan and Ina Rae Hark. London: Routledge, 1993: 1-20.

Cyrino, Monica Silveira. Big Screen Rome. Oxford: Blackwell Publishing, 2006.

Devore, Gary. "'I'M QUEER!' 'No! I'M QUEER!': Hollywood Homosexuality and Roman Epic Films." Popular Culture Review 10 (February 1999): $127-38$.

Endres, Nikolai. Roman Homosexuality: Ideologies of Masculinity in Classical Antiquity. Baltimore: Johns Hopkins University Press, 2000.

Fava, Claudio G. and Aldo Vigano. The Films of Federico Fellini. New York: Citadel Press, 1990.

Fellini, Federico. Comments on Film, ed. G. Grazzini, translated by Joseph Henry. Fresno: California State University, 1988.

Foucault, Michel. Madness and Civilisation: A History of Insanity in the Age of Reason. New York: Pantheon Books, 1965.

. Discipline and Punish: The Birth of the Prison. Vancouver: Vintage Books, 1979.

. The History of Sexuality. Vol. 1, The History of Sexuality: An Introduction. New York: Vintage Books, 1990.

. The History of Sexuality. Vol. 2, The Use of Pleasure. New York: Vintage Books, 1990.

Fuss, Diana, ed. Inside/Out: Lesbian Theories, Gay Theories. London: Routledge: 1991.

Jeff, Leonard J. and Jerold Simmons, eds., "The Motion Picture Production Code of 1930." The Dame in the Kimono: Hollywood, Censorship, and the Production Code from the 1920s to the 1960s. New York: Grove Wiedenfeld, 1990. 285-290.

Joshel, Sandra R., Margaret Malamud and Donald T. Maguire, Jr. eds. Imperial Properties: Ancient Rome in Modern Popular Culture. Baltimore: Johns Hopkins University Press, 2001. 
Hall, Mark A.. "Romancing the Stones: Archaeology in Popular Cinema," European Journal of Archaeology 7, no. 2 (2004): 159-176.

Hallett, Judith P. and Marilyn B. Skinner, eds. Roman Sexualities. Princeton: University Press, 1997.

Ina Rae Hark. "Animals or Romans" in Screening the Male ed. Steve Cohan and Ina Rae Hark. New York: Routledge, 1993: 151-172.

Landy, Marcia. The Historical Film: History and Memory in the Media. New Brunswick: Rutgers University Press, 2000.

Leprohon, Pierre. The Italian Cinema. Translated by Roger Greaves and Oliver Stallybrass. New York: Praeger, 1972.

Magid, Ron. "Rebuilding ancient Rome." American Cinematographer May 2000: 54-59.

Mora, Carl J. "The Image of Ancient Rome in the Cinema". Film Historia 7, no. 3 (1997): 221-243.

Rotha, Paul and Griffith, Richard. The Film Til Now. London: Spring Books, 1967.

Schickedanse, Hans-Joachim. Aktein Akadien. Harenberg: Die Bibliophilen Taschenbucher, 1987.

Solomon, Jon. The Ancient World in the Cinema. New York: A. S. Barnes, 1977.

- "In the Wake of Cleopatra: The Ancient World in the

Cinema Since 1963." Classical Journal 91 (December 1995-January 1996): 113-40.

Stern, N. S. G. "Great Caesar's ghost--whose version of history is Gladiator?" Architectural Record July 2000, 27.

Waugh, Thomas. Hard to Imagine: Gay Male Eroticism in Photography and Film from Their Beginnings to Stonewall. New York: Columbia University Press, 1996. 
Williams, Craig A. Roman Homosexuality: Ideologies of Masculinity in Classical Antiquity. New York: Oxford University Press, 1999.

Winkler, Martin ed. Classics and Cinema. Lewisburg: Bucknell University Press, 1991.

ed. Classical Myth and Culture in the Cinema. New York: Oxford University Press, 2001.

ed. Gladiator: Film and History. Oxford: Blackwell Publishing, 2004.

ed. Spartacus: Film and History. Oxford: Blackwell Publishing, 2007.

. "The Roman Empire in American Cinema after 1945." Classical Journal 93, (December 1997-January 1998): 167-196.

Woody, Jack ed. Taormina - Wilhem von Gloeden. 3rd ed. Santa Fe: Twelve Trees Press, 1993.

Wyke, Maria. Projecting the Past: Ancient Rome, Women and History. New York: Routledge, 1994.

"Ancient Rome and the Traditions of Film History." Screening the Past, no. 6 (1999): 32. 


\section{Filmography}

Ben-Hur. Fred Niblo, dir. MGM, 1925.

Cabiria - Visione Storica del Terzo Secolo A. C. Giovanni Pastrone, dir. Itala, 1914.

Demetrius and the Gladiators. Delmer Daves, dir. Twentieth Century Fox, 1954.

Fiddlers Three. Harry Watt, dir. Ealing Studios, 1943.

Fellini Satyricon. Federico Fellini, dir. Les Productions Artistes Associés, 1969.

Gladiator. Ridley Scott, dir. Dreamworks SKG, 2000.

Quo Vadis. Mervyn Leroy, dir. MGM, 1951.

The Robe. Henry Koster, dir. Twentieth Century Fox, 1953.

Sebastiane. Derek Jarman, dir. Cinegate, Ltd., 1976.

Sign of the Cross. Cecil B. DeMille, dir. Paramount Pictures,1932.

Spartacus. Stanley Kubrick, dir. Bryna Productions, 1960. 